\title{
Perancangan Vending Machine Menggunakan Uang Kertas Berbasis Arduino
}

\author{
Vicky Mora Alkautsar ${ }^{1}$, Irma Husnaini ${ }^{2 *}$, \\ 1,2 Jurusan Teknik Elektro, Fakultas Teknik Universitas Negeri Padang \\ e-mail:vicluser1@gmail.com
}

\begin{abstract}
Abstrak - Pesatnya perkembangan teknologi pada saat ini sangat memudahkan perekonomian masyarakat khususnya dalam hal jual-beli. Kemudahan dalam melakukan jual-beli salah satu kunci untuk meningkatkan efektifitas dalam meningkatkan pendapatan bagi masyarakat. Vending machine adalah salah satu alat yang dibutuhkan untuk membantu memudahkan perekonomian bagi masyarakat dalam hal jual-beli. Tulisan ini bertujuan merancang sebuah vending machine yang bekerja berdasarkan pendeteksian uang yang dimasukkan. Alat ini menggunakan TCS 3200-DB sebagai sensor untuk mendeteksi uang dan menggunakan arduino sebagai pusat kontrol serta pemroses data. Pada saat uang sudah terbaca oleh sensor TCS 3200-DB, maka LCD akan menampilkan nominal uang yang masuk. Setelah jumlah uang mencapai total Rp. 5000,- maka servo akan aktif dengan membuka katup besi yang di rancang khusus untuk mengeluarkan minuman yang sudah di pilih. Hasil pengujian alat Vending Machine ini menujukkan bahwa alat ini sudah bekerja sesuai dengan rancangan yang diinginkan, dimana alat bekerja dengan baik dan mampu mengenali uang kertas Rp. 1000, 2000 dan 5000,- dengan tingkat keberhasilan 86.6\%.
\end{abstract}

Kata Kunci : Arduino, TCS 3200-DB, Servo, $\quad L C D$.

Abstract- The development of technology nowadays greatly facilitates the people's economy, especially in terms of buying and selling. Ease of buying and selling is one of the keys to increasing effectiveness in increasing income for the community. Vending machines are one of the tools needed to help facilitate the economy for the community in terms of buying and selling. This paper aims to design a device and system using a power source. This tool uses TCS 3200-DB as a sensor to detect money and uses Arduino as a control center and data processor. When the money has been read by the TCS 3200-DB sensor, the LCD will display the amount of incoming money. After the amount of money reaches a total of Rp. 5000, then the servo will be active by opening the iron valve which is specially designed to release the drink that has been selected. The results of testing the Vending Machine using Arduino are in accordance with the desired design, and have worked properly. The tool that was designed was working properly and was able to recognize Rp. 1000, 2000 and 5000, - with $86.6 \%$ success.

Keywords: Arduino, TCS 3200-DB, Servo, LCD.

\section{PEndahuluan}

Perkembangan teknologi telah banyak merambah dalam bidang makanan dan minuman yang sering digunakan, salah satu contohnya yaitu pada minuman instan yang banyak dikonsumsi saat ini. Minuman instan tersebut sering ditemukan di tempat-tempat keramaian dan tempat-tempat wisata. Vending machine sendiri telah banyak digunakan untuk memudahkan konsumen membeli makanan dan terkhusus minuman ringan. Dengan begitu proses jual-beli dapat lebih mudah, praktis, dan tidak menghabiskan waktu yang banyak merupakan pertimbangan utama manusia dalam melakukan aktivitas[1].

Pada saat ini vending mesin yang di gunakan masih banyak memiliki kelemahan sebagai contoh, vending mesin dengan menggunakan uang koin (koin akseptor). Permasalahan yang sering ditemukan pada saat menggunakan koin akseptor atau uang koin adalah kurang efektifnya uang koin pada saat ini seperti beratnya masa dari uang koin itu sendiri dan juga tidak semua dari konsumen yang memiliki atau membawa uang koin. Selanjutnya kelebihan dari vending machine sendiri adalah memudahkan manusia atau mengurangi human error untuk melakukan transaksi jual-beli sehingga memaksimalkan hasil dari penjualan produk minuman[2].

Tulisan ini bertujuan untuk merancang sebuah mesin penjual (vending machine) yang dapat mendeteksi nominal uang kertas yang dimasukan. Semua proses kerja mesin ini dikontrol dengan mengunakan arduino. 
Kelebihan alat ini adalah menggunakan sensor TCS-3200 DB untuk mengetahui warna dari uang kertas. Tulisan ini bermanfaat untuk memudahkan konsumen dan pembeli dalam melakukan jual-beli serta memberikan referensi kepada pembaca tentang vending machine.

\section{Vending Machine}

Vending machine merupakan perangkat yang dapat melakukan transaksi secara otomatis dengan memasukkan sejumlah nominal uang ke dalam sebuah mesin, kemudian mesin dapat merespon dengan mengeluarkan item atau barang tertentu[3]. Perangkat ini dapat digunakan pada sistem penjualan otomatis makanan ringan, minuman ringan (soft drink), koran, tiket atau makanan instan. Di area publik seperti bandara internasional Minangkabau, departement store, halte bis trans Jakarta dapat kita jumpai perangkat vending machine ini, sehingga pelanggan dapat membeli minuman tanpa bertransaksi dengan manusia. Keuntungannya adalah cepat, praktis, bersih dan tidak membutuhkan ruang luas.

Mesin vending yang digunakan pada umumnya memiliki prinsip kerja yang sama, ketika konsumen memasukkan sejumlah uang ke dalam mesin tersebut, kemudian konsumen dapat memilih produk yang diinginkan dengan menekan tombol yang mewakili produk tersebut dan kemudian produk akan keluar melalui tempat yang telah disediakan, contoh output dari mesin vending tersebut adalah minuman instan, konsumen hanya tinggal memilih minuman yang diinginkan karena biasanya setiap vending mesin mewakili minuman instan tertentu.

\section{Microcontroler Arduino Uno ATMega328p}

Arduino Uno adalah sebuah board yang menggunakan mikrokontroler ATmega328[4]. Arduino Uno memiliki 14 pin digital (6 pin dapat digunakan sebagai output PWM), 6 input analog, sebuah $16 \mathrm{MHz}$ osilato kristal, sebuah koneksi USB, sebuah konektor sumber tegangan, sebuah header ICSP, dan sebuah tombol reset.

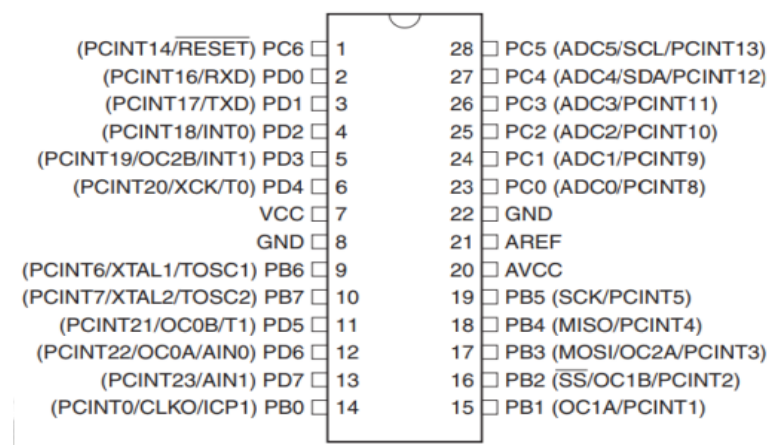

Gambar 1. Konfigurasi Pin ATmega328.

\section{Sensor warna TCS3200-DB}

Sensor warna TCS3200-DB adalah sensor terprogram yang terdiri dari 64 buah fotodioda sebagai pendeteksi intensitas cahaya pada warna objek serta filter frekuensi sebagai tranducer yang berfungsi untuk mengubah arus menjadi frekuensi. Selain itu sensor tersebut memiliki lensa fokus yang berguna untuk mempertajam pendeteksian fotodioda terhadap intensitas cahaya dengan jarak pembacaan $2 \mathrm{~mm}$ dari lensa IC[6].

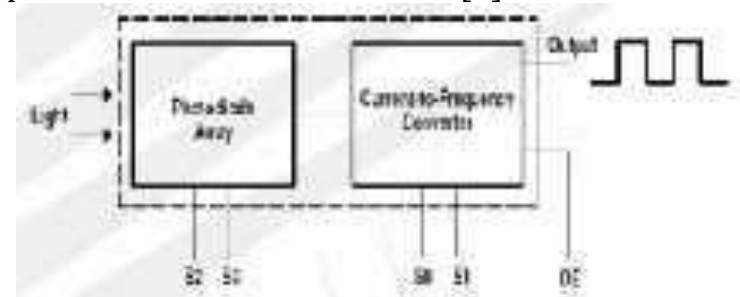

Gambar 2. Proses sensor TCS3200.-DB.

\section{Motor Servo}

Motor servo adalah sebuah perangkat atau aktuator putar (motor) yang dirancang dengan sistem kontrol umpan balik loop tertutup (servo), sehingga dapat di set-up atau di atur untuk menentukan dan memastikan posisi sudut dari poros output motor. motor servo merupakan perangkat yang terdiri dari motor DC, serangkaian gear, rangkaian kontrol dan potensiometer. Serangkaian gear yang melekat pada poros motor DC akan memperlambat putaran poros dan meningkatkan torsi motor servo, sedangkan potensiometer dengan perubahan resistansinya saat motor berputar berfungsi sebagai penentu batas posisi putaran poros motor servo[8].

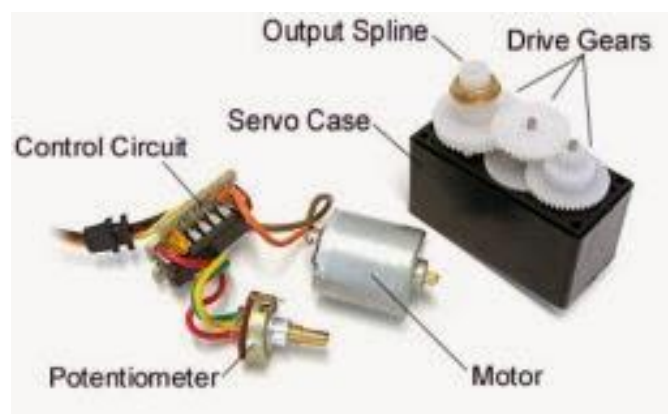

Gambar 3. Komponen pada motor servo.

\section{LCD (Liquid Crystal Display)}

LCD (Liquid Crystal Display) merupakan sebuah display dot matrix dimana dapat difungsikan sebagai menampilkan tulisan berupa angka atau huruf sesuai dengan yang diinginkan (sesuai dengan program yang digunakan untuk mengontrolnya)[9]. Penulis menggunakan LCD 
dot matrix dengan karakter $2 \times 16$, sehingga kaki-kakinya berjumlah 16 pin.

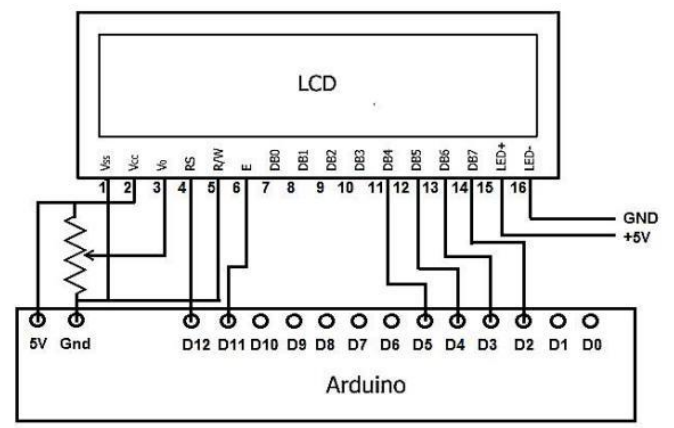

Gambar 4. Rangkaian LCD (Liquid Crystal Display).

\section{METODE}

Metode yang digunakan dalam perancangan alat ini adalah percobaan atau eksperimen. Berikut blok diagram alat yang dirancang :

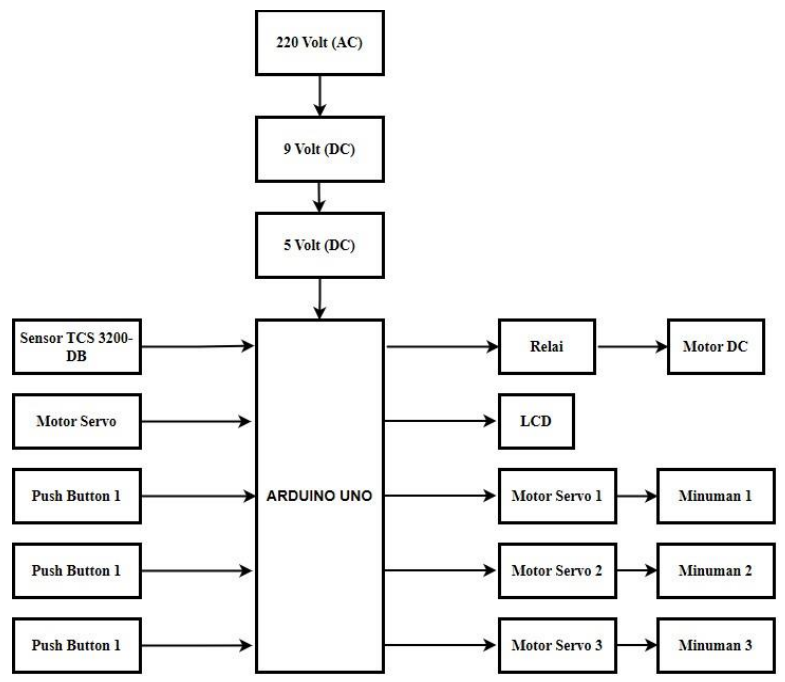

Gambar 5. Blok Diagram

Prinsip kerja Vending machine ini diawali dari menekan saklar untuk menghubungkan dengan sumber listrik 220VAC. Tegangan 220VAC diolah oleh rangkaian elektronika daya menjadi tegangan keluaran 9 VDC dan 5VDC yang nantinya akan menyuplai sensor,arduino dan komponen lainya pada vending machine.

Langkah selanjutnya masukan uang kertas dengan nomial Rp.5000 rupiah pada tempat yang telah disedikan. Sensor TCS3200-DB akan mengolah warna pada uang kertas tersebut apa bila tidak di kenali maka LCD akan memberikan informasi bahwa uang tersebut tidak dikenali dan dikembalikan, sebaliknya apabila di kendali maka LCD akan menampilkan info nominal uang yang terbaca lanjut pada proses selanjutnya.
Proses selanjutnya pemilihan jenis minuman dimana pembeli hanya perlu menekan tombol yang telah disediakan yang sesuai dengan minuman yang di inginkan selanjutnya minuma tersebut akan di dorong oleh motor servo sehingga keluar di tempat yang telah di sediakan dan dapat di ambil.

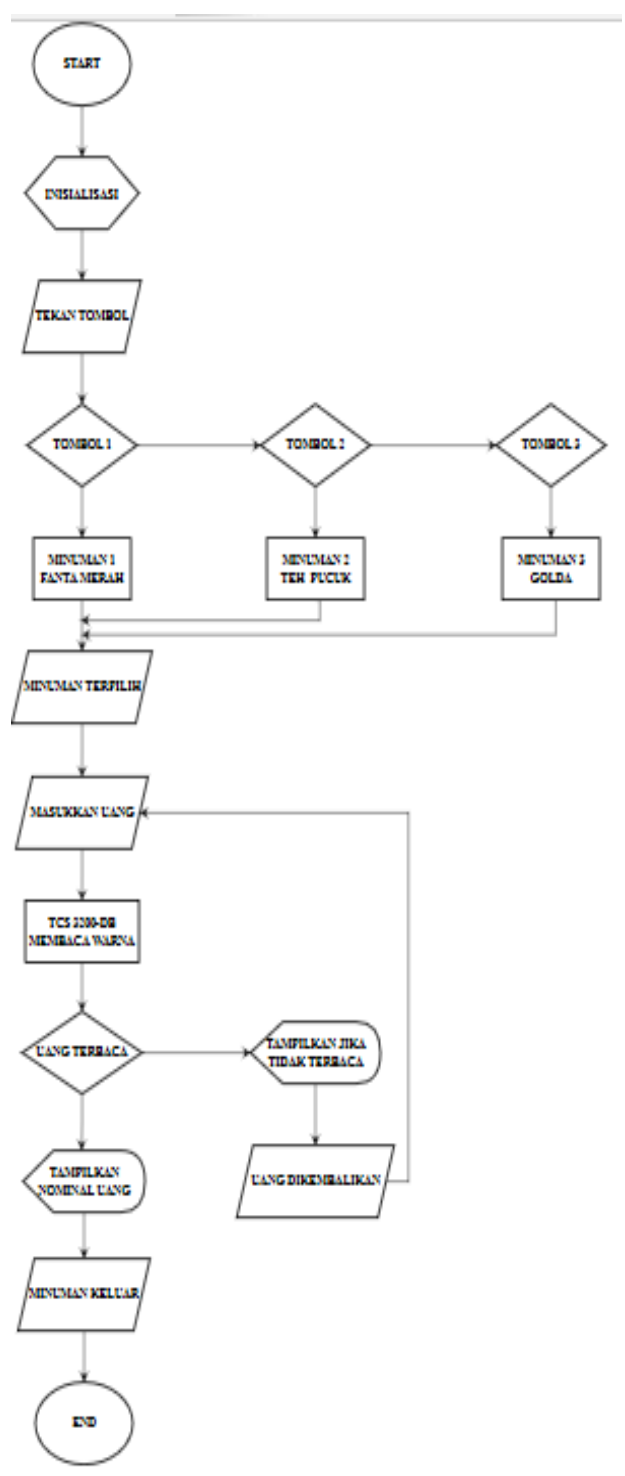

Gambar 6. Flowchart Sistem. 
Adapun rangkaian alat keseluruhan dapat dilihat pada gambar 7 .

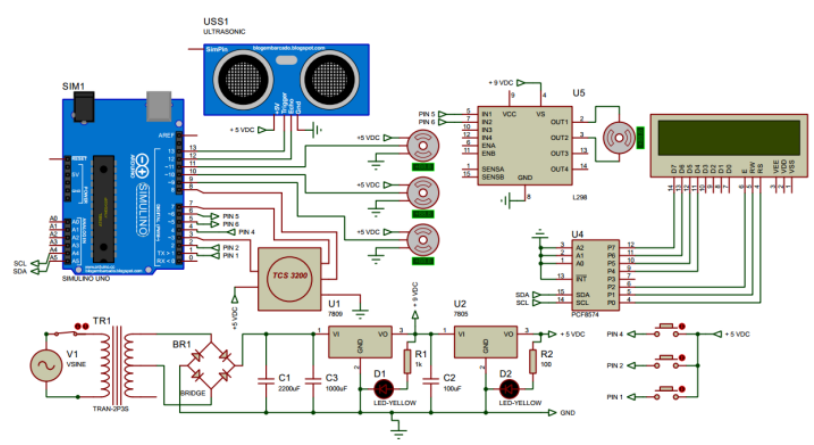

Gambar 7. Rangkaian Keseluruhan

\section{HASIL DAN PEMBAHASAN}

Terdapat beberapa percobaan dan pengujian alat untuk sistem yan g telah dibuat. Pengujian alat di lakukan untuk melihat sejauh mana kinerja dari sistem dan alat yang telah dibuat secara Software maupun Hardware.

Adapun uraian hasil dari sistem ini dapat kita lihat di bawah ini :

\section{Hasil Rancangan Mekanik}

Pengujian mekanik bertujuan untuk membandingkan hasil perancangan pada bab 3 dengan hasil jadi pada pembuatan. Pada perancangan Tugas Akhir ini menggunakan mikrokontroler Arduino Mega sebagai pusat pengontrolan sistem. Adapun yang akan dikontrol yaitu sensor TCS32000-DB, motor servo, relay, dan motor DC Perancangan sistem akan dikemas dalam sebuah prototype dalam bentuk box. Kotak mekanik yang digunakan berbentuk balok dengan ukuran panjang $50 \mathrm{~cm}$, lebar $30 \mathrm{~cm}$ dan tinggi $40 \mathrm{~cm}$.

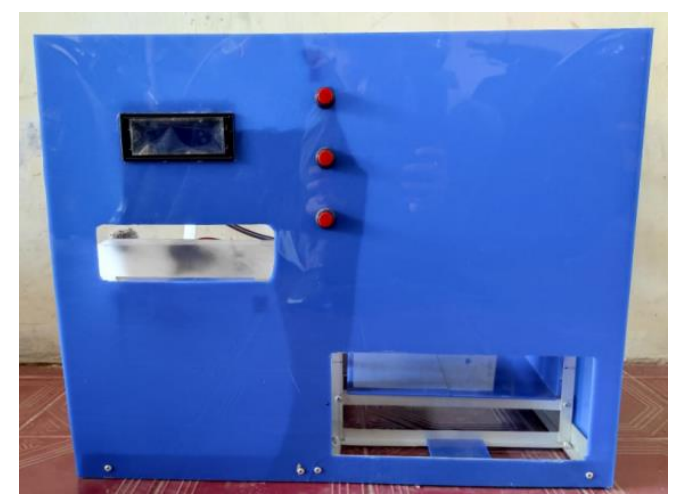

Gambar 8. Tampak Depan

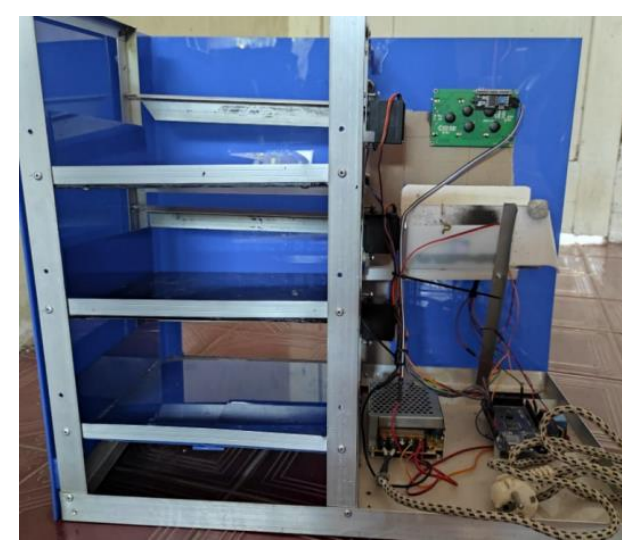

Gambar 9. Tampak Belakang

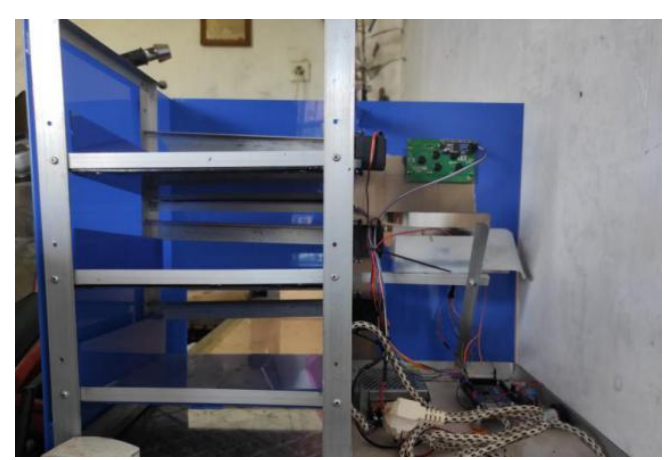

Gambar 10. Tampak Samping

2. Pengujian Pendeteksi Uang kertas dengan sensor warna TCS 3200-DB

Tabel 1. Hasil Pengujian Uang kertas Rp.1000

\begin{tabular}{|c|c|c|c|c|}
\hline $\begin{array}{l}\text { Jenis } \\
\text { uang } \\
\text { kertas }\end{array}$ & $\begin{array}{l}\text { Perc } \\
\text { obaa } \\
\text { n } \\
\text { Ke- }\end{array}$ & $\begin{array}{l}\text { Proses } \\
\text { Penarika } \\
\text { n }\end{array}$ & $\begin{array}{l}\text { Tampilan } \\
\text { LCD }\end{array}$ & Keterangan \\
\hline \multirow{5}{*}{$\frac{101}{8}$} & 1 & Ya & 1000 & $\begin{array}{c}\text { Uang } \\
\text { terdeteksi }\end{array}$ \\
\hline & 2 & Ya & 1000 & $\begin{array}{c}\text { Uang } \\
\text { terdeteksi }\end{array}$ \\
\hline & 3 & Tidak & 0 & $\begin{array}{l}\text { Uang tidak } \\
\text { terdeteksi }\end{array}$ \\
\hline & 4 & Ya & 1000 & $\begin{array}{c}\text { Uang } \\
\text { terdeteksi }\end{array}$ \\
\hline & 5 & Ya & 1000 & $\begin{array}{c}\text { Uang } \\
\text { terdeteksi }\end{array}$ \\
\hline
\end{tabular}

Berdasarkan data yang telah diambil untuk pengujian uang Rp. 1000 dapat diambil kesimpulan bahwa TCS 3200 DB telah bekerja dengan baik yakni dengan pembacaan $80 \%$ dengan cahaya yang memadai serta kondisi dari uang yang diinputkan sesuai dengan yang diinginkan. 
Tabel 2. Hasil Pengujian Uang kertas Rp.2000 dan 5000

\begin{tabular}{|c|c|c|c|c|}
\hline $\begin{array}{c}\text { Jenis } \\
\text { uang } \\
\text { kertas }\end{array}$ & $\begin{array}{c}\text { Percobaa } \\
\text { n } \\
\text { Ke- }\end{array}$ & $\begin{array}{c}\text { Proses } \\
\text { Penarika } \\
\text { n }\end{array}$ & $\begin{array}{l}\text { Tampilan } \\
\text { LCD }\end{array}$ & Keterangan \\
\hline \multirow{5}{*}{ (8) } & 1 & Ya & 5000 & $\begin{array}{c}\text { Uang } \\
\text { terdeteksi }\end{array}$ \\
\hline & 2 & Ya & 5000 & $\begin{array}{c}\text { Uang } \\
\text { terdeteksi }\end{array}$ \\
\hline & 3 & Ya & 5000 & $\begin{array}{c}\text { Uang } \\
\text { terdeteksi }\end{array}$ \\
\hline & 4 & Ya & 5000 & $\begin{array}{c}\text { Uang } \\
\text { terdeteksi }\end{array}$ \\
\hline & 5 & Ya & 5000 & $\begin{array}{c}\text { Uang } \\
\text { terdeteksi }\end{array}$ \\
\hline
\end{tabular}

Berdasarkan tabel 2 diatas dapat dilihat bahwa hasil pengujian uang Rp.2000 memiliki persentase yang cukup tinggi yakni $80 \%$ keberhasilan dalam pembacaan. Hanya saja RGBW dari uang Rp.2000 sangat memiliki kesamaan dengan uang seribu sehingga sangat sulit membedakan atau menentukan RGBW dari uang kertas nominal Rp.2000 ini. Sedangkan pengujian nominal Rp.5000 memiliki persentase $\quad 100 \%$ keberhasilan.

\section{Hasil Pengujian keseluruhan}

Hasil pengujian alat keseluruhan diperlihatkan pada tabel 3.

Tabel 3. Hasil Pengujian Keseluruhan Sistem Pada

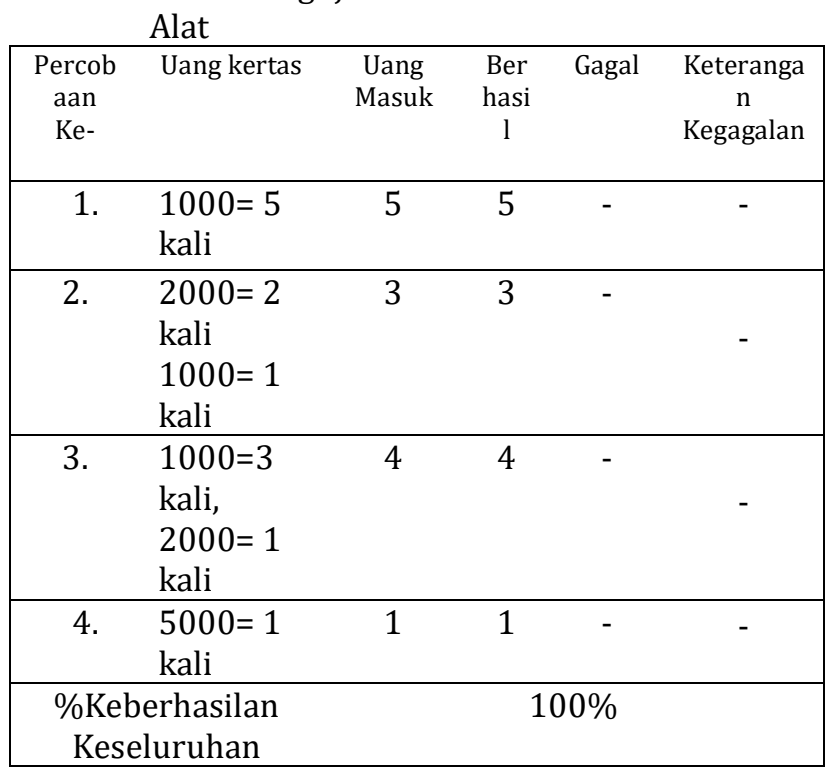

Tabel 3 memperlihatkan hasil pengujian alat secara keseluruhan, persentase keberhasilan keseluruhan pengujian pada vending machine yaitu sebanyak 100\%. Dari hasil pengujian yang telah di lakukan dapat di simpulkan bahwa alat dapat bekerja dengan baik hanya saja alat tidak dapat

\begin{tabular}{|ccccc|}
\hline $\begin{array}{c}\text { Jenis } \\
\text { kertas } \\
\text { kertas }\end{array}$ & $\begin{array}{c}\text { Percob } \\
\text { aan } \\
\text { Ke- }\end{array}$ & $\begin{array}{l}\text { Proses } \\
\text { Penarik } \\
\text { an }\end{array}$ & $\begin{array}{l}\text { Tampila } \\
\text { n } \\
\text { LCD }\end{array}$ & Keterangan \\
\hline & 1 & Ya & 2000 & $\begin{array}{c}\text { Uang } \\
\text { terdeteksi }\end{array}$ \\
\cline { 2 - 5 } & 2 & Ya & 2000 & $\begin{array}{c}\text { Uang } \\
\text { terdeteksi }\end{array}$ \\
\hline & 3 & Ya & 2000 & $\begin{array}{c}\text { Uang } \\
\text { terdeteksi }\end{array}$ \\
\hline & & Ya & 2000 & $\begin{array}{c}\text { Uang } \\
\text { terdeteksi }\end{array}$ \\
\hline & & & & Uang tidak \\
& & Tidak & 0 & terdeteksi \\
\hline
\end{tabular}

mendeteksi uang kertas yang lama dan juga kurangnya pencahayaan terhadap sensor TCS 3200-DB ketika membaca uang kertas.

\section{PENUTUP}

Berdasarkan pengujian yang telah dilakukan hasil perancangan dan pengujian alat sudah sesuai dengan apa yang di harapkan. Untuk pengujian uang kertas nominal masing-masing Rp. 1000, Rp.2000 dan Rp.5000 dengan 5 kali percobaan memberikan tingkat keberhasilan masing -masing 80\%, 80\% dan 100\% Tingkat keberhasilan alat dalam mengenali uang kertas yang diuji secara keseluruhan mencapai 100\%.

\section{REFERENSI}

[1]. Dodi S Adiputra. Mesin Penjual Softdrink berbasis AtMega 8535. Jurnal Politek Caltex Riau, 1(2), 1-4. 2015.

[2]. Yosephine Carolina, Marta Puspa Wangi dan Hanjaya Siaputra, SE., MA. Faktor Minat Beli Produk Minuman di Vending Machine (Studi Kasus Mahasiswa UK Putra). Jurnal Program Studi Manajemen Fakultas Ekonomi Universitas Kristen Jl Siwalankerto, 1(2), 1-2. 2020.

[3]. Adiputra, D. S., \& Subagiyo, H. Mesin Penjual Softdrink Otomatis Berbasis ATMega8535. Jurnal Elektro dan Mesin Terapan, 1(2), 29-38. 2015.

[4]. Arisandi, E. D. Kemudahan Pemrograman Mikrokontroller Arduino Pada Aplikasi Wahana Terbang. Setrum: Sistem Kendali-Tenaga-elektronika-telekomunikasi-kompu ter, 3(2), 114-117. 2016.

[5]. Arisandi, E. D. Kemudahan Pemrograman Mikrokontroller Arduino Pada Aplikasi Wahana Terbang. Setrum: Sistem Kendali Tenaga 
elektronika-telekomunikasi-komputer, 2(2), 12. 2016.

[6]. Risma, P. Sensor Pemilih Warna. Teliska, 4(3). 2012.

[7]. Andhika Rendy Pratama dan Ir. Ratna Adil M.T. Desain Mekanik alat bantu untuk Identifikasi Kualitas Susu Cair dan Sari Buah dengan Sensor Warna TCS 3200. Jurnal Teknik Elektronika PENS-ITS 1(2), 1-2. 2008.

[8]. Aries Andry Afriady. Excavator dengan menggunakan Arduino dan Motor Servo, 2(4), 20 dan 3(2), 48. 2014.

[9]. Zain, Ruri Hartika. Sistem Keamanan Ruangan Menggunakan Sensor Passive Infra Red (Pir) Dilengkapi Kontrol Penerangan Pada Ruangan Berbasis Microcontroler Atmega8535 Dan Real Time Clock Ds1307. Jurnal Teknologi Informasi \& Pendidikan Vol. 6 No. 1 Maret 2013.

[10].www.http://zonaelektro.net/motor-servo/komponen -penyusun-motor-servo/

\section{Biodata Penulis}

Vicky Mora Alkautsar dilahirkan di Perkebunan Sei Lala, 11 September 1997, menyelesaikan Program Studi DIV Teknik Elektro Industri pada jurusan Teknik Elektro Fakultas Teknik Universitas Negeri Padang.

Irma Husnaini,ST,MT, dilahirkan di Bukittinggi, 29 September 1972, menyelesaikan Program S1 di Universitas Negeri Padang dan S2 di Institut Teknologi Bandung, Staff pengajar tetap di jurusan Teknik Elektro Fakultas Teknik Universitas Negeri Padang sampai sekarang. 